\title{
VASCULARISED VITREORETINOPATHY: THE ROLE OF GROWTH FACTORS
}

\author{
M. E. BOULTON, D. FOREMAN and D. McLEOD \\ Manchester
}

Vascularised vitreoretinopathies, otherwise designated vasoproliferative retinopathies (VPRs), ${ }^{1}$ are common disorders affecting the retinal circulation and constitute a major cause of visual impairment and blindness in the Western world. VPRs may be induced by a local disorder such as retinal vein occlusion, or by systemic disease which ultimately affects the ocular circulation such as proliferative diabetic retinopathy (PDR). The underlying feature of all VPRs is retinal capillary closure and nonperfusion which results in inner retinal ischaemia and subsequent preretinal neovascularisation. ${ }^{2.3}$

\section{THE ROLE OF GROWTH MODULATORS IN VASOPROLIFERATIVE RETINOPATHIES}

The concept of diffusible, chemical agents as inducers and perpetuators of VPRs was advanced by Michaelson over 40 years ago. ${ }^{4}$ Studies using in vitro assays have led to the identification and characterisation of a large number of factors which stimulate angiogenesis (see reviews ${ }^{5-7}$ ). However, these mitogens (usually polypeptides) are produced by a variety of cell types with a wide spectrum of biological activity. Furthermore, the majority of these growth modulators are general mitogens and are not usually specific for vascular cells. Although most of these mitogens are designated growth factors, this is probably a misnomer since they not only affect cell proliferation but also regulate migration, turnover of extracellular matrix, production of adhesion molecules, differentiation and a variety of other intrinsic biological activities. A number of growth modulators have been implicated in preretinal neovascularisation, in particular fibroblast growth factor (FGF), platelet-derived growth factor (PDGF), epidermal growth factor (EGF),

\footnotetext{
Presented in part at the Vitreous Symposium, Annual Congress of the Royal College of Ophthalmologists, 1995.

Correspondence to: Dr M. Boulton, University Department of Ophthalmology, Manchester Royal Eye Hospital, Oxford Road, Manchester M13 9WH, UK.
}

insulin-like growth factor I (IGF-I), insulin-like growth factor binding proteins and transforming growth factor beta (TGF- $\beta$ ) (Table I). However, a relative newcomer to the field of ocular angiogenesis is vascular endothelial growth factor (VEGF). ${ }^{8}$ VEGF, also known as vascular permeability factor owing to its ability to increase blood vessel permeability, is a heparin binding polypeptide with a target cell specificity allegedly confined to vascular endothelial cells. ${ }^{8-10}$ However, recent studies demonstrate that VEGF is an autocrine growth factor for human retinal pigment epithelial cells. ${ }^{11}$ Molecular cloning has revealed the existence of four species of VEGF (comprising 121, 165, 189 and 206 amino acids respectively) which are encoded by the same gene and arise from alternative splicing of mRNA. ${ }^{10}$ The four resulting polypeptides have strikingly different secretion patterns, suggesting multiple physiological roles for this family of proteins. VEGF is structurally related to PDGF, exhibiting an $18-20 \%$ amino acid sequence homology. ${ }^{10}$ Expression of VEGF is observed in a wide variety of untransformed (including retinal) and transformed cell types both in vivo and in vitro. ${ }^{10-12}$ VEGF expression is commonly associated with vascularisation, thus highlighting a prominent role for VEGF in angiogenesis. ${ }^{9}$

\section{GROWTH FACTOR RECEPTORS}

The induction of DNA synthesis and other biological effects of growth factors depend upon their interaction with specific, high-affinity receptors within cell membranes. The function of a growth factor is therefore to activate receptors rather than to participate directly in the intracellular mechanisms determining cell behaviour. Consequently, growth factor receptors not only confer cell-type specificity for growth factors but also define the biochemical identity of the subsequent intracellular events. The molecular characteristics of a variety of different growth factor receptors reveal that they fall into defined families based on their structure and 
Table I. Angiogenic growth factors and their actions

\begin{tabular}{|c|c|c|c|c|}
\hline \multirow[b]{2}{*}{ Growth factor } & \multirow{2}{*}{$\begin{array}{l}\text { Angiogenesis } \\
\quad(\text { in vivo })\end{array}$} & \multicolumn{2}{|c|}{ Endothelial cells in vitro } & \multirow{2}{*}{$\begin{array}{l}\text { Endothelial } \\
\text { cell specific }\end{array}$} \\
\hline & & Migration & Proliferation & \\
\hline Acidic FGF & $\checkmark$ & $\uparrow$ & $\uparrow$ & No \\
\hline Basic FGF & $\checkmark$ & $\uparrow$ & $\uparrow$ & No \\
\hline $\mathrm{EGF}$ & $\checkmark$ & $\uparrow$ & $\uparrow$ & No \\
\hline IGF-I & $\checkmark$ & $\uparrow$ & $\uparrow$ & No \\
\hline PDGF & $\checkmark$ & $\uparrow$ & $\uparrow$ & No \\
\hline TGF- $\beta$ & $\checkmark$ & No & $\downarrow$ & No \\
\hline VEGF & $\checkmark$ & $\uparrow$ & $\uparrow$ & $?$ \\
\hline
\end{tabular}

$\widehat{\checkmark}$, yes; $\uparrow$, stimulatory; $\downarrow$, inhibitory.

biochemical actions. The most important receptor families in the context of the growth factors which are believed to have a role in the VPRs use the tyrosine kinase receptors (i.e. FGF, PDGF, VEGF, IGF-I and EGF $)^{8,13}$ or the serine/threonine kinase receptors (i.e. TGF- $\beta$ ). ${ }^{14}$ An additional aspect of target cell specificity is that each growth factor may react with more than one receptor. Five receptors for FGF, two PDGF receptors and three TGF- $\beta$ receptors have so far been identified. ${ }^{13-15}$ Finally, receptor regulation adds a further level of control; the rate of receptor synthesis and degradation will determine receptor density and thus the level of the cellular response from its associated ligand. ${ }^{13}$

\section{METHODS OF STUDYING THE ROLE OF GROWTH FACTORS IN THE \\ VASOPROLIFERATIVE RETINOPATHIES}

In the absence of a practical animal model with which to study preretinal neovascularisation, research into the role of growth factors in the VPRs has relied either on the analysis of intraocular samples removed during closed microsurgery in diabetic patients (i.e. vitreous fluid or preretinal membranes) or on in vitro studies. ${ }^{7}$ Although cell culture provides invaluable information on growth factor production and responsiveness by isolated retinal cells, the results obtained are difficult to equate with, and extrapolate to, the in vivo situation. The following review will concentrate on the growth factors and their receptors identified in samples from patients with PDR.

\section{VITREOUS LEVELS OF GROWTH FACTORS IN THE VASOPROLIFERATIVE RETINOPATHIES}

Studies to date have clearly demonstrated that the levels of many potent angiogenic factors are elevated in vitreous from patients with VPRs when compared with vitreous from patients without any preretinal vasoproliferation. The growth factor accumulation may derive from one or more of a variety of sources including the (ischaemic) retina, the blood circulation (via a breach in the blood-retinal barrier) or the fibrovascular membranes themselves (as indicated by growth factor mRNA expression in the membranes ${ }^{7}$ ).
Growth modulators whose intravitreal levels have been shown to be elevated in PDR include IGF-I, bFGF, VEGF and TGF- $\beta .^{16-20}$ The levels of these growth factors in PDR appear to correlate with both the activity of neovascularisation and the type of diabetes. Vitreous levels of bFGF are higher in eyes with active neovascularisation than in eyes with fibrotic proliferations, ${ }^{18-20}$ and this also appears to be true for IGF-I, TGF- $\beta$ and VEGF. ${ }^{19.20}$ Furthermore, a recent study has suggested that growth factor levels in the vitreous correlate with the type of diabetes, ${ }^{20}$ bFGF being prominent in non-insulintreated diabetes mellitus and IGF-I and TGF- $\beta$ prominent in insulin-treated diabetes mellitus. To what extent IGF-I is active in the vitreous is open to debate, since significant levels of IGF binding proteins (IGFBPs) can be found in the vitreous. ${ }^{17.21}$ These IGFBPs bind to IGF-I, producing an inactive complex, and thus control its biological activity. ${ }^{22} \mathrm{~A}$ recent report infers that FGF activity in the vitreous may also be modulated, in this instance by soluble forms of a high-affinity FGF receptor. ${ }^{23}$ Thus, it has to be acknowledged that the mere presence of a growth factor in the vitreous does not necessarily imply a pathophysiological role for that factor; its biological effect may be neutralised. By the same token, rapid metabolism of a growth factor may account for its low concentration while concealing its true role.

\section{PRERETINAL LOCALISATION OF GROWTH FACTORS AND THEIR RECEPTORS}

Immunocytochemical studies have localised $\mathrm{bFGF}^{24}$ IGF-I, ${ }^{25}$ EGF and TGF- $\alpha,{ }^{26}$ PDGF $^{27}$ (Fig. 1), TGF- $\beta$ (Fig. 2) and VEGF (Fig. 3) to normal retina and to preretinal fibrovascular membranes. The intensity of staining for these growth factors in preretinal membranes was generally higher than that in the normal retina. The staining pattern has varied between individual membranes, whether diffuse or localised to cells within the membrane, but no significant correlation has been found between immunostaining and cell type. Furthermore, the receptors for EGF/TGF- $\alpha$ and for PDGF have been co-localised to areas of growth factor staining in preretinal membranes and are generally localised to the vessels. ${ }^{26.27}$ 


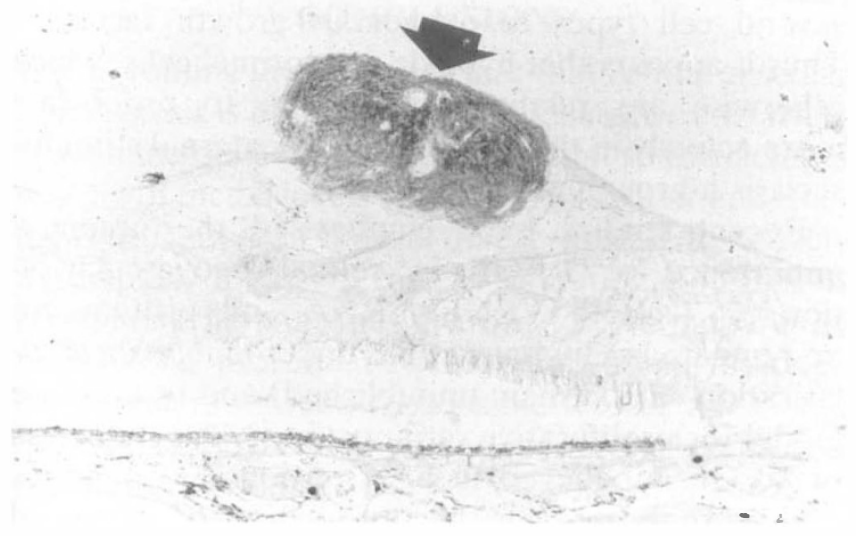

Fig. 1. Photomicrograph demonstrating immunostaining for PDGF in a diabetic preretinal membrane and associated retina. Immunohistochemistry was undertaken as previously described. ${ }^{26}$ In brief, $4 \mu \mathrm{m}$ thick wax-embedded sections were dewaxed, incubated with $0.1 \%$ chymotrypsin and an anti-human PDGF-AB antibody (Upstate Biotechnology) applied for 1 hour. After washing, sections were exposed to an anti-rabbit IgG conjugated to biotin (Dako). Samples were subsequently incubated with an avidin-biotin alkaline phosphatase reaction complex and antibody binding visualised using a naphthol phosphatelfast red substrate mixture. Immunostaining patterns for PDGF exhibited intense staining located throughout the membrane (arrow). $\times 120$.

Although immunohistochemistry is a widely accepted technique for demonstrating the presence of antigenic determinants, it does not necessarily demonstrate the site of synthesis. Interestingly, mRNA for VEGF, IGF-I, TGF- $\beta$, EGF and bFGF have all been localised to cells within preretinal membranes. ${ }^{7,28}$ However, Malecaze et $a .^{28}$ used reverse transcriptase-polymerase chain reaction (RT-PCR) to determine growth factor expression in 14 neovascular membranes and reported that VEGF was the only growth factor consistently expressed in all the membranes.

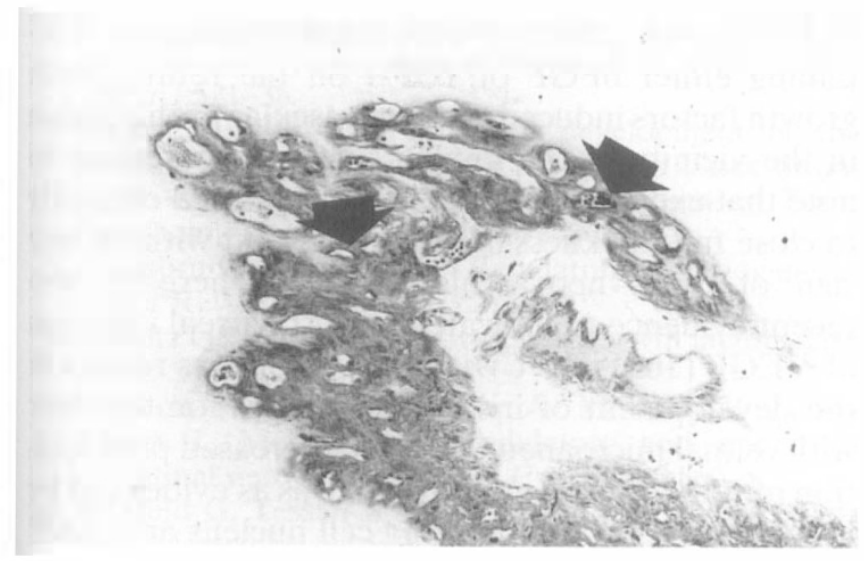

Fig. 2. Photomicrograph demonstrating immunostaining for TGF- $\beta$ in an excised diabetic preretinal membrane. Sections were immunostained as described in Fig. 1 using a pan-specific anti-TGF- $\beta$ primary antibody ( $R \& D$ Systems). Immunostaining for TGF- $\beta$ in the membrane was diffuse, but the highest intensity of staining was localised to vascular cells (arrows). $\times 120$.

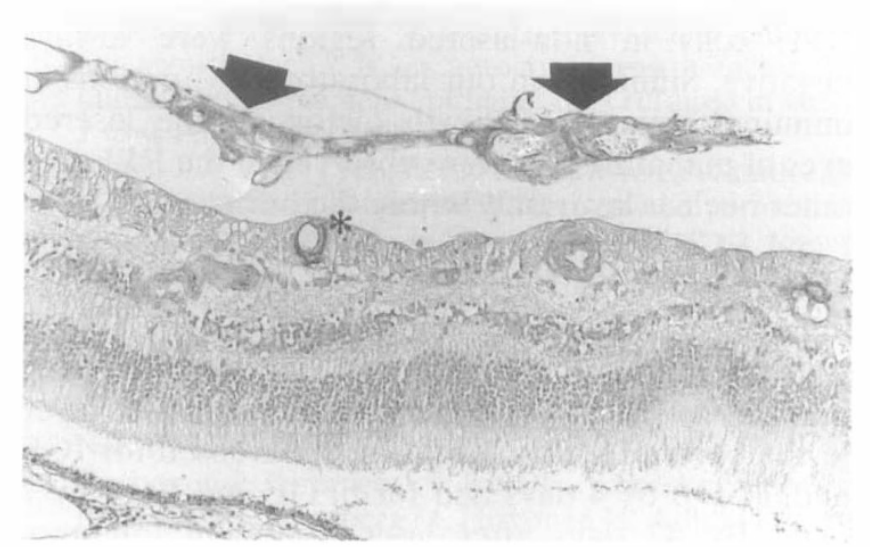

Fig. 3. Photomicrograph demonstrating immunostaining for VEGF in a diabetic preretinal membrane and associated retina. Sections were immunostained as described in Fig. 1 using an anti-human VEGF primary antibody (R\&D Systems). Immunostaining patterns for VEGF are similar to those shown for PDGF with intense staining located throughout the membrane (arrows) and to the inner retinal vessels underlying the membrane (*). $\times 120$.

The presence of growth factors, their receptors and their mRNA within diabetic retina and preretinal membranes is strong support for a paracrine/ autocrine role for growth factors in the genesis and perpetuation of neovascular membranes.

\section{EFFECT OF SCATTER RETINAL PHOTOCOAGULATION ON INTRAOCULAR GROWTH FACTORS}

The exact mechanism of new vessel regression following retinal photocoagulation remains unclear despite empirical success in treating the VPRs with laser. However, a number of hypotheses have been put forward:

1. Destruction of ischaemic inner retina decreases the production of angiogenic factors. ${ }^{29}$

2. Destruction of outer retinal tissue makes more oxygen and nutrients available to the remaining retina from the choroid. ${ }^{30}$

3. Disruption of the outer blood-retinal barrier facilitates outward diffusion of angiogenic factors. $^{31}$

4. Photocoagulation injury stimulates the production of an 'inhibitory' factor which induces regression of new vessels. ${ }^{32}$

While little is known about the expression of growth factors in the retina following laser photocoagulation, it is likely that growth factor profiles will change owing to the associated wound healing process. Unfortunately, most investigations in this area have necessarily been undertaken in normal retinas. Zhang et al. ${ }^{33}$ found that retinal pigment epithelium (RPE) cells in laser-treated regions of the rat retina immunostained for both $\mathrm{aFGF}$ and bFGF from 4 to 80 days following laser treatment, while 
RPE cells in non-lasered regions were always negative. Similarly, in our laboratories, variations in immunostaining for growth factors in the lasered eyes of miniature pigs were observed in the RPE and outer nuclear layer only within the burn area. ${ }^{34}$ IGFI and EGF staining intensity in the RPE decreased by 4 days but had returned to normal by 21 days following laser treatment while bFGF and TGF- $\beta$ staining in the RPE remained constant. Staining intensity for growth factors in the outer nuclear layer in the burn area was significantly increased for IGF and TGF- $\beta$ by 4 days and for bFGF and EGF by 7 days. By 42 days after laser treatment immunoreactivity for all growth factors returned to the level seen in the control retina. ${ }^{34}$ Immunostaining for TGF- $\beta$ and VEGF has also been examined in diabetic eyes following photocoagulation. Lutty et $a l .{ }^{35}$ observed that the TGF- $\beta$ immunoreactivity present in normal retina was absent in the photocoagulated scars, whilst immunoreactivity appeared to be increased in adjacent retinal areas. We have observed that the retinal VEGF immunoreactivity normally present in diabetic eyes is reduced in lasered diabetic retinas.

Vitreous levels of growth factors following retinal laser photocoagulation have been studied in the rabbit and miniature pig. Intravitreal TGF- $\beta_{2}$ levels decreased 2 and 14 days after laser treatment in rabbit eyes compared with non-lasered control eyes. ${ }^{36}$ By contrast, we have shown a significant increase in intravitreal TGF- $\beta_{2}$ levels at 4 and 7 days after laser in the miniature pig when compared with normal eyes and eyes 21 days after laser treatment. ${ }^{34}$ The discrepancy between these two studies is probably a reflection of inter-species differences; rabbits have a largely avascular retina while the pig inner retina is fully vascularised. Intravitreal levels of IGF-I also increased at 4 and 7 days after laser treatment in the pig model while levels of bFGF and EGF were unaffected. ${ }^{34}$

\section{HYPOXIC CONTROL OF GROWTH FACTORS}

Retinal capillary non-perfusion and inner retinal hypoxia are features common to all the VPRs. While it has been postulated that hypoxia promotes the release of growth factors from the ischaemic retina, which then stimulate preretinal angiogenesis from adjacent vessels, ${ }^{4}$ low oxygen levels at the vitreoretinal interface may also modulate growth factor activity and cell responsiveness in preretinal membranes. In vitro studies have shown that (a) hypoxia modulates cell proliferation, ${ }^{37}$ with reduced mitosis at very low oxygen levels, (b) hypoxia increases production of IGF-I $\mathrm{I}^{7}$ and VEGF, 38.39 (c) hypoxia decreases production of $\mathrm{bFGF}$ and TGF- $\beta, 40$ (d) hypoxia up-regulates bFGF and EGF receptors, ${ }^{41}$ and (e) hypoxia increases the responsiveness of several cell types to exogenous growth factors. ${ }^{41}$ Thus it appears that hypoxia can 'prime' cells, which otherwise are relatively quiescent, to proliferate more actively in the presence of an external stimulus such as a growth factor.

Recent studies have emphasised the potential importance of VEGF in retinal neovascularisation. ${ }^{12.42-44}$ Both VEGF mRNA and protein are up-regulated in human retinas undergoing neovascularisation $^{43}$ (Foreman, unpublished) and in a mouse model for proliferative retinopathy. ${ }^{12}$ This induction of VEGF is believed to be a response to hypoxia. This is supported by the observation of increased VEGF mRNA expression in the retina of both monkeys and rabbits following experimentally induced retinal ischaemia. ${ }^{42.43}$ Furthermore, ischaemia-induced retinal neovascularisation in mice is suppressed by administration of soluble VEGFreceptor chimeric proteins, further emphasising the importance of VEGF in retinal neovascularisation. ${ }^{44}$

\section{INTRAOCULAR ADMINISTRATION OF GROWTH FACTORS}

Given the correlation between high intravitreal growth factor levels and the VPRs, and the localisation of growth factors to preretinal membranes, many researchers have attempted to induce preretinal neovascularisation by intraocular administration of growth factors. Intravitreal injection of bFGF into cats and rabbits resulted in increased DNA synthesis in retinal venular and capillary endothelial cells ${ }^{45.46}$ with a preferential response in the venular endothelial cells compared with that in capillaries. ${ }^{45}$ Furthermore both bFGF and IGF-I induced retinal fibrovascular proliferation when injected into the vitreous cavity of rabbits. ${ }^{47}$ The same study also examined the effect of slow-release chambers containing either bFGF or IGF-I on the retina. Both growth factors induced areas of vascular proliferation in the vicinity of the implants. ${ }^{47}$ It is interesting to note that exogenous TGF- $\beta_{2}$ has been used clinically to close full-thickness macular holes but without any sign of overt neovascularisation. ${ }^{48}$ There is also recent evidence to indicate that intravitreal injection of VEGF (165) into Cynomolgus monkeys results in the development of iris neovascularisation together with retinal microaneurysms and increased proliferation of retinal vessel endothelial cells as evidenced by immunostains to proliferating cell nucleus antigen. ${ }^{49}$

These injection studies further emphasise the importance of growth factors in eliciting a neovascular response in the retina. However, it has to be conceded that the concentrations of growth factors (achieved by injection) in the vicinity of the target cell receptors, and the state of receptor regulation, are unknown and might be non-physiological. 


\section{CONCLUSIONS}

It is becoming increasingly clear that retinal vascular homeostasis is dependent on the balance of a variety growth factors within the eye and that subtle changes in growth factor levels can release vascular endothelial cells from their normal quiescent state to actively participate in new vessel formation. VEGF is prominent among the growth factors apparently involved in preretinal neovascularisation, although other factors may be responsible for the associated fibrosis. Hypoxia is a potent modulator of growth factor production and cell responsiveness in vitro and may have a role in retinal angiogenesis. It is conceivable that blocking growth factor action in the VPRs will be an alternative therapeutic approach to scatter photocoagulation in the future. Strategic approaches might include the use of neutralising antibodies to the growth factors or their receptors, genetically engineered peptides that bind to receptors without initiating any intracellular metabolic events, soluble receptors that compete with target cell membrane receptors for ligand binding, and receptor antagonists and antisense nucleotides that prevent growth factor expression by the secreting cells.

Our studies are supported by the Wellcome Trust, Guide Dogs for the Blind Association, British Diabetic Association, the Manchester Royal Eye Hospital Research Endowments, Fight for Sight and the North Western Regional Health Authority.

Key words: Retinopathy, Diabetes, Growth factors, Hypoxia.

\section{REFERENCES}

1. Boulton M, McLeod D, Garner A. Vasoproliferative retinopathies: clinical, morphogenetic and modulatory aspects. Eye 1988;2(Suppl):S124-39.

2. Ashton N. Arteriolar involvement in diabetic retinopathy. Br J Ophthalmol 1953;37:282-92.

3. Ashton N. Studies of retinal capillaries in relation to diabetic and other retinopathies. $\mathrm{Br} \mathrm{J}$ Ophthalmol 1963;47:521-38.

4. Michaelson IC. The mode of development of the vascular system of the retina, with some observations on its significance for certain retinal diseases. Trans Ophthalmol Soc UK 1948;68:137-86.

5. Klagsbrun N, D'Amore P. Regulators of angiogenesis. Annu Rev Physiol 1991;53:217-39.

6. Schultz GS, Grant M. Neovascular growth factors. Eye 1991;5:170-80.

7. Boulton M, Patel B, Khaliq A, Moriarty P, JarvisEvans J, McLeod D. Modulators and milieu in preretinal neovascularisation. Eye 1992;6:560-5.

8. Neufeld G, Tessler S, Gitay-Goren H, Cohen T, Levi B-Z. Vascular endothelial growth factor and its receptors. Prog Growth Factor Res 1994;5:89-97.

9. Connolly D. Vascular permeability factor: a unique regulator of blood vessel function. J Cell Biochem 1991;47:219-23.

10. Ferrara N, Houck K, Jakeman L, Winer J, Leung D. The vascular endothelial growth factor family of polypeptides. J Cell Biochem 1991;47:211-8.

11. Guerrin M, Moukadiri H, Chollet P, Moro F, Dutt K,
Malecaze F, Plouet J. Vasculotropin/vascular endothelial growth factor is an autocrine growth factor for human retinal pigment epithelial cells cultured in vitro. J Cell Physiol 1995;164:385-94.

12. Pierce EA, Avery RL, Foley ED, Aiello LP, Smith LE. Vascular endothelial growth factor/vascular permeability factor expression in a mouse model of retinal neovascularisation. Proc Natl Acad Sci USA 1995;92:905-9.

13. Heath JK. Growth factors. Oxford: IRL Press, 1993.

14. Wrana J, Attisano L, Wieser R, Ventura F, Massague $\mathrm{J}$. Mechanism of activation of the TGF- $\beta$ receptor. Nature 1994;370:341-6.

15. Korhonen J, Partanen J, Eerola E, Vainikka S, Alitalo R, Makela T, Sandberg M, Hirvonen H, Alitalo K. Five FGF receptors with distinct expression patterns. In: Steiner R, Langer R, editors. Angiogenesis: key principles. Basel: Birkhauser, 1992: 91-100.

16. Grant M, Russell B, Fitzgerald C, Merimee T. Insulinlike growth factors in vitreous: studies in control and diabetic subjects with neovascularisation. Diabetes 1986;35:416-20.

17. Meyer-Schwickerath R, Pfeiffer A, Blum F, Freyberger $\mathrm{H}$, Klein M, Losche C, Rollman R, Schatz H. Vitreous levels of the insulin-like growth factors I and II, and the insulin-like growth factor binding proteins 2 and 3 , increase in neovascular eye disease: studies in nondiabetic and diabetic subjects. J Clin Invest 1993;92:2620-5.

18. Sivalingham A, Kenney J, Brown G, Benson W, Donoso L. Basic fibroblast growth factor levels in the vitreous with proliferative diabetic retinopathy. Arch Ophthalmol 1991;108:869-72.

19. Aiello L, Avery L, Arrigg P, Keyt B, Jampel H, Shah S, et al. Vascular endothelial cell growth factor in ocular fluid of patients with diabetic retinopathy and other retinal disordes. N Engl J Med 1994;331:1480-7.

20. Gregor Z, Moriarty P, Khaliq A, McLeod D, Boulton M. Growth factor levels in the diabetic vitreous: correlation with type of diabetes and neovascular activity. Invest Ophthalmol Vis Sci 1995;36:S441.

21. Waldbillig R, Jone E, Schoen T, Moshayedi P, Heidersbach S, Bitar M, van Kuijk F, de Juan E, Kador P, Chader G. Vitreal insulin-like growth factor binding proteins (IGFBPs) are increased in human and animal diabetics. Curr Eye Res 1994;13:539-46.

22. Shimasaki S, Ling N. Identification and molecular characterisation of insulin-like growth factor binding proteins (IGFBP-1, -2, -3, -4, -5 and -6). Prog Growth Factor Res 1992;3:243-66.

23. Hanneken A, Baird A. Soluble forms of the highaffinity fibroblast growth factor receptor in human vitreous fluid. Invest Ophthalmol Vis Sci 1995; 36:1192-9.

24. Hanneken A, deJuan E, Lutty G, Fox G, Schiffer S, Hjelmand L. Altered distribution of basic fibroblast growth factor in diabetic retinopathy. Arch Ophthalmol 1991;109:1005-11.

25. Fredj-Reygrobellet D, Baudoin C, Negre F, Caruelle J, Gastaud P, Lapalus P. Acidic FGF and other growth factors in preretinal membranes from patients with diabetic retinopathy and proliferative vitreoretinopathy. Ophthalmic Res 1991;23:154-61.

26. Patel B, Hiscott P, Charteris D, Mather J, McLeod D, Boulton M. Retinal and preretinal localisation of epidermal growth factor, transforming growth factor alpha, and their receptor in proliferative diabetic retinopathy. Br J Ophthalmol 1994;78:714-8.

27. Robbins S, Mixon R, Wilson D, Hart C, Robertson J, 
Westra I, Planck S, Rosenbaum J. Platelet-derived growth factor ligands and receptors immunolocalised in proliferative retinal diseases. Invest Ophthalmol Vis Sci 1994;35:3649-63.

28. Malecaze F, Clamens S, Simorre-Pinatel V, Mathis A, Chollet P, Favard C, Bayard F, Plouet J. Detection of vascular endothelial growth factor messenger RNA and vascular endothelial growth factor-like activity in proliferative diabetic retinopathy. Arch Ophthalmol 1994;112:1476-82.

29. Patz A. Clinical and experimental studies on retinal neovascularisation. Am J Ophthalmol 1982;94:715-43.

30. Weiter J, Zuckerman R. The influence of the photoreceptor-RPE complex on the inner retina: an explanation for the beneficial effects of photocoagulation. Ophthalmology 1980;87:1133-9.

31. McNaught E, Foulds W, Johnson N. The permeability of the posterior blood-retinal barrier after xenon coagulation: a study using fluorescein labelled dextrans. Br J Ophthalmol 1981;65:473-7.

32. Glaser B, Campochairo P, Davis J, Jerdan J. Retinal pigment epithelial cells release inhibitors of neovascularisation. Ophthalmology 1987;94:780-4.

33. Zhang N, Samadani E, Frank R. Mitogenesis and retinal pigment epithelial cell mitogen expression in the rat after krypton laser photocoagulation. Invest Ophthalmol Vis Sci 1993;34:2412-24.

34. Xiao M. A study of cellular responses to retinal laser photocoagulation in the miniature pig. $\mathrm{PhD}$ thesis, University of Manchester, 1995.

35. Lutty G, Ikeda K, Chandler C, McLeod D. Immunohistochemical localisation of transforming growth factor- $\beta$ in human photoreceptors. Curr Eye Res 1991;10:61-74.

36. Ie D, Gordon L, Glaser B, Pena P. Transforming growth factor-beta2 levels increase following retinal laser photocoagulation. Curr Eye Res 1991;10:61-74.

37. Boulton M, Khaliq A, McLeod D, Moriarty P. Effect of hypoxia on the proliferation of microvascular cells in vitro. Exp Eye Res 1994;59:243-6.

38. Shweiki D, Itin A, Soffer D, Keshet E. Vascular endothelial cell growth factor induced by hypoxia may mediate hypoxia-initiated angiogenesis. Nature 1992;359:843-5.

39. Shima D, Adamis A, Ferrara N, Yeo K, Yeo T, Allende D, Folkman J, D'Amore P. Hypoxic induction of endothelial cell growth factors in retinal cells: identification and characterisation of vascular endothe- lial growth factor (VEGF) as the mitogen. Molecular Med 1995;1:182-93.

40. Khaliq A, Patel B, Jarvis-Evans J, Moriarty P, McLeod $\mathrm{D}$, Boulton M. Oxygen modulates production of bFGF and TGF- $\beta$ by retinal cells in vitro. Exp Eye Res 1995;60:415-24.

41. Khaliq A. The effect of oxygen on the production of, and response to growth factors by retinal cells in vitro: its relationship to the vasoproliferative retinopathies. $\mathrm{PhD}$ thesis, University of Manchester, 1994.

42. Miller J, Adamis A, Shima D, D'Amore P, Moulton R, et al. Vascular endothelial growth factor/vascular permeability factor is temporally and spatially correlated with ocular angiogenesis in a primate model. Am J Pathol 1994:145:574-84.

43. Pe'er J, Schweiki D, Itin A, Hemo I, Gnessin H, Keshet E. Hypoxia-induced expression of vascular endothelial growth factor by retinal cells is a common factor in neovascular diseases. Lab Invest 1995;72:615-8.

44. Aiello L, Pierce E, Foley E, Takagi H, Chen H, Riddle L, Ferrara N, King G, Smith L. Suppression of retinal neovascularisation in vivo by inhibition of vascular endothelial growth factor (VEGF) using soluble VEGF-receptor chimeric proteins. Proc Natl Acad Sci USA 1995;92:10457-61.

45. de Juan E, Stefansson E, Ohiro A. Basic fibroblast growth factor stimulates $\left[{ }^{3} \mathrm{H}\right]$-thymidine uptake in venular and capillary endothelial cells in vivo. Invest Ophthalmol Vis Sci 1990;31:1238-44.

46. Lewis G, Erickson P, Guerin C, Anderson D, Fisher S. Basic fibroblast growth factor: a potential regulator of proliferation and intermediate expression in the retina. J Neurosci 1992:12:3968-78.

47. Grant M, Mames R, Fitzgerald C, Ellis E, Aboufriekha M, Guy J. Insulin-like growth factor-I acts as an angiogenic agent in rabbit cornea and retina: comparative studies with basic fibroblast growth factor. Diabetologia 1993;36:282-91.

48. Glaser B, Michels R, Kupperman B, Sjaarda R, Pena $R$. Transforming growth factor- $\beta_{2}$ for the treatment of full-thickness macular holes. Ophthalmology 1992;99:1162-72.

49. Tolentino M, Miller J, Gragoudas E, Moulton R, Chazistefanou $\mathrm{K}$, et al. Vascular endothelial growth factor is sufficient to produce ocular neovascularisation in a non-human primate. Invest Ophthalmol Vis Sci 1995;36:S402. 